Railway Engineering

Jan. 2022

Issue: 15, Page: 60-74

Research Article

doi: 10.47072/demiryolu.944301

http://dergipark.org.tr/demiryolu

e-ISSN: 2687-2463, ISSN: 2149-1607

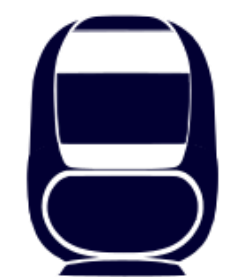

\title{
Türkiye Demiryolu Araçları, Tramvaylar ve Komponentleri Sektörünün Uluslararası Rekabet Gücü Analizi
}

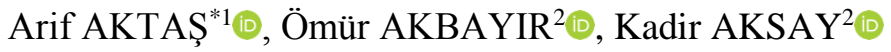 \\ ${ }^{1}$ Anadolu Raylı Ulaşım Sistemleri Kümelenmesi, Ankara, Türkiye \\ ${ }^{2}$ Eskişehir Teknik Üniversitesi, Ulaştırma MYO, Eskişehir, Türkiye \\ *arif.aktas2626@gmail.com
}

(Alınış/Received: 28.05.2021, Kabul/Accepted: 22.01.2022, Yayımlama/Published: 31.01.2022)

\begin{abstract}
Öz: Demiryolu endüstrisi birçok ülkeyi hem ekonomik hem de ticari olarak bugünkü haline getirmeye yardımcı olmuş, en önemli altyapı endüstrilerindendir. Günümüzde de birçok ülkenin ekonomisini geliştirmeye artan oranda katkı sağlamaktadır. Bu çalışmanın amacı, Türk demiryolu araçları ve komponentleri sektörünün rekabet gücünü farklı analiz yöntemleri ile analiz etmektir. Bu bağlamda Türk raylı sistemler sektörünün rekabet gücü, Açıklanmış Karşılaştırmalı Üstünlükler -diğer adıyla Balassa Endeksi- (RTA, BI), Nispi Ticaret Avantajı (RCA) ve Açıklanmış Rekabet Üstünlüğü (RC) göstergeleriyle analiz edilmiştir. Yapılan analiz sonucunda; Türk raylı sistemler sektörünün Dünya piyasasında belirli bir rekabet gücüne ulaşamadığı ancak son yıllarda pozitif yönlü bir ivme yakaladığı görülmüştür. Bu bağlamda küresel ölçekte yaşanan yoğun rekabet, söz konusu sektöre yönelik yeni politikalar geliştirilmesi ve inovatif ürünlerin geliştirilmesine odaklanılmasıyla mevcut rekabet gücünün yükseltilmesini gerekli kılmaktadır.
\end{abstract}

Anahtar kelimeler: Demiryolu araçları, Uluslararası Rekabet Gücü, RCA, RTA, RC

\section{International Competitiveness Analysis of Turkish Railway Vehicles, Trams and Components Sector}

\begin{abstract}
The railway industry is one of the most important infrastructure industries, helping many countries to become what they are today, both economically and commercially. Today, it contributes to the development and recovery of the economy of many countries at an increasing level. This study aims to analyze the competitiveness of the Turkish railway vehicles, trams, and components sector with different analysis methods. In this context, the competitiveness of the Turkish rail systems sector has been analyzed with the indicators of revealed comparative advantages, also known as the Balassa Index (RCA, BI), Relative Trade Advantage (RTA, BI), and The Revealed Competitive Advantage Index (RC). As a result of the analysis, the Turkish railway vehicles, trams, and components sector has not reached a certain competitive power in the world market but has gained positive momentum in recent years. In this context, the intense competition experienced on a global scale makes it necessary to increase the current competitiveness by focusing on the development of new policies for the sector in question and the development of innovative products.
\end{abstract}

Keywords: Railway vehicles, International Competitiveness, RCA, RTA, RC

\section{Giriș}

2000'li yıllarla birlikte raylı sistemler güvenli ulaşım, çevresel sürdürülebilirlik ve maliyet üstünlüğü gibi konularda diğer ulaşım sistemlerine göre daha avantajlı olması nedeniyle tüm dünyada yeniden popülerlik kazanmıştır. Son yıllarda "hız" kavramının demiryolu araçlarına entegrasyonu, demiryolunu ulaşım ve lojistikte tercih edilen modlardan biri haline getirmiştir [1]. Türkiye'de demiryolculuk; Osmanlı Devleti'nın son dönemlerine doğru başlamış; siyasi ekonomik ve askeri sebeplerden dolayı önemli bir yere sahip olmuştur. Türkiye Cumhuriyeti'nin kurulmasıyla birlikte demiryollarının önemi daha da artarak, ülke bir uçtan 
diğer uca demiryolu ağlarıyla örülmeye başlanmıştır. 1940'lı yıllara gelindiğinde ülkemizde demiryolları tüm Dünya genelinde olduğu gibi önemsiz bir ulaşım modu olarak görülmüştür. Dünyadaki eğilimlere benzer şekilde, devletin yatırım politikalarında değişikliğe gidilerek, 1950'li yıllardan bu yana neredeyse hiç gerçekleşmeyen demiryolu yatırımlarına daha fazla önem verilerek demiryollarının itibarı yükselmiştir. [2].

Son yıllardaki gelişmelere bağlı olarak hafif raylı sistemler, banliyö ve yüksek hızlı trenler performans artışı açısından en dinamik sektörel alt segmentler arasına girmiştir. Banliyö oldukça yaygındır ve metropolitan alanlardaki yolcu taşımacılığına odaklanmaktadır. Uygulamas1, özellikle önceki demiryolu altyapısı mevcutsa nispeten basittir. Bununla birlikte, yüksek hızlı trenler hala çoğu gelişme seviyesi yüksek olan birkaç ülke ile sınırlıdır. Bunun temel nedeni, bu teknolojiyle bağlantılı yüksek uygulama maliyetidir. Güney Amerika, Orta Amerika, Afrika ve Avustralya / Pasifik gibi pek çok bölgede yüksek hızlı hizmetler hala mevcut değildir ve yalnızca Kuzey Amerika'da ve Rusya'da sınırlı bir seviyede uygulanmaktadır. Çin, bu açıdan önemli bir istisnadır, çünkü dünyanın en büyük hızlı tren raylı sistem ağını kısa sürede geliştirmeyi başarmıştır.

Diğer yandan yüksek yakıt fiyatları, trafik tıkanıklığı ve sera gazı emisyonları gibi zorluklarla karşı karşıya kalan toplu taşıma araçları, özel otomobil seyahatiyle karşılaştırıldığında hala avantajlı durumdadır [3]. Artan demiryolu ve otobüs seferleri ile yüksek hızlı demiryolu hatları, ülkelerin demiryoluna ilgisini yeniden canlandırmıştır. Demiryolu projeleri için fonlar daha hızlı artmaktadır. Daha güçlü ulaşım sistemlerine olan ilgiyle birlikte, bu araçların üretiminin artmasıyla gelişen istihdam oranları da devletler için sektöre yatırımı cazip kılmaktadır. Bu ilginin neticesinde demiryolu araçları toplam demiryolu pazarının yaklaşık üçte birini oluşturmuştur, kentsel hafif raylı sistemler ve metrolar dünyanın birçok bölgesinde genişlemekte ve şehirlerarası yüksek hızlı tren hatlarına yatırımlar artmaktadır [4]. Sektörün önemli ülkeleri, demiryolu araç imalatında toplamda en az yarım milyon kişiye istihdam sağlamakta ve tedarik zincirinde çok daha fazla istihdam yaratmaktadır. Hatların, tesislerin ve diğer altyapıların inşası; Ar-Ge ve mühendislik; iletişim ve sinyal ekipmanlarının üretimi gibi alanlar büyük istihdamlar yaratmakta, ayrıca demiryolu ve transit sistemlerinin çalıştırılmasında istihdam, dünya genelinde milyonlarca kişiye ulaşmaktadır. Almanya, İspanya, Japonya, Çin, Güney Kore, $\mathrm{ABD}$ ve Kanada demiryolu sektörünün önde gelen ülkeleri arasında yer almaktadır. Üretim değeri açısından bakıldığında demiryolu araçları piyasası, demiryolu sektörü için hemen hemen her pazar bölümüyle eşleşen, en geniş ve yaygın demiryolu alt sektörüdür. Sinyalizasyon ve elektrifikasyon alt sektörü ise demiryolu araçları alt sektörünü takip etmektedir.

Bu çalışma ihracat ve ithalata dayılı rekabet gücü analizi üzerinedir. Rekabet gücü analizleriyle ilgili alan yazına bakıldığında Türkiye demiryolu araçları sektörüne yönelik yapılan bir çalışmaya rastlanmamıştır. Mevcut çalışmalar, çoğunlukla sektörün hali hazırdaki görünüşünü ortaya çıkarmak maksadıyla bazı kurum ve kuruluşlar tarafından hazırlanan çalışma grubu raporlarıdır. Bu çalışmalarda daha çok sektöre ait üretim, tüketim, ihracat ve ithalat ile ilgili bilgiler verilerek, sektörün mevcut durumuna yönelik öneriler geliştirilmiştir [5-7]. Birçok sektörde yapılan çalışmalar rekabet gücü analizi demiryolu araçları sektörüne ilk kez uygulanacaktır. Bu bağlamda çalışmanın amacı, Türkiye'nin demiryolu araçları, tramvaylar ve komponentleri sektörüne yönelik uluslararası rekabet gücünü belirlemeye çalışmaktır.

Uluslararası rekabet gücünü ölçmede en yaygın biçimde kullanılan bir yöntem olan Açıklanmış Karşılaştırmalı Üstünlükler metodu çalışmada kullanılmıştır. Hesaplamalar için Balassa 'nın [8] ortaya koyduğu "karşılaştırmalı üstünlükler endeksi" (RCA) ve "ithalat verileriyle açıklanmış karşılaştırmalı üstünlükler endeksi" (RCA) ile Vollrath'ın [9] "nispi ticaret avantajı endeksi" (RTA) ve "açıklanmış rekabet üstünlüğü endeksi" (RC)'den yararlanılmıştır. 2010-2020 periyoduna göre hesaplanan değerler birbirleriyle karşılaştırılıp ayrıntılı incelemeler ortaya 
konmuştur. Bu çalışmanın diğer önemli bir özelliği; Vollrath ve Balassa tarafından geliştirilen endeksleri harmanlayarak Türkiye "Demiryolu Araçları, Tramvaylar ve Komponentleri" sektörünün daha ayrıntılı bir analizle dört haneli alt sektörlerin de hesaplamalara katılması, 10 yıllık süreçteki değişimin ayrıntılı bir şekilde incelenmesidir.

Çalışma beş bölümden meydana gelmektedir. İlk bölüm giriş bölümü olup ardından Dünya ve Türkiye'deki demiryolu araçları, tramvaylar ve komponentleri sektörü hakkında genel bilgiler aktarılmıştır. Daha sonra, kullanılan metot ortaya konmuştur. Çalışmadaki metot ve veri seti hakkındaki detaylı bilgilerin ardından, son bölümde endeksler hesaplanmış ve sonuçlar yorumlanmıştır. Çalışmanın sonunda önerilere ve genel sonuçlara yer verilmiştir.

\section{Demiryolu Araçları, Tramvaylar ve Komponentleri Sektörü}

1829 yılının Ekim ayında İngiliz Stephenson'un "ROCKET" isimli lokomotifi üretmesiyle başlayan demiryolu sektörü, zamanla ticari hatlarının inşa edilmesi ve işletilmesiyle, 1940'lara kadar dünyadaki en önemli ulaştırma modu olmuştur. 1940'ların ardından otomotiv sektörünün gelişmesiyle, global çapta karayolu taşımacılığı gelişmeye başlamış, zamanla demiryollarının ulaşım modları arasındaki üstünlüğü son bulmuştur [5].

Hafif raylı sistemler, banliyö ve yüksek hızlı trenler performans artışı açısından en dinamik alt segmentler arasındadır. Banliyö oldukça yaygındır ve metropolitan alanlardaki yolcu taşımacılığına odaklanmaktadır. Uygulaması, özellikle önceki demiryolu altyapısı mevcutsa nispeten basittir. Bununla birlikte, yüksek hızlı trenler hala çoğu gelişme seviyesi yüksek olan birkaç ülke ile sınırlıdır. Bunun temel nedeni, bu teknolojiyle bağlantılı yüksek uygulama maliyetidir. Güney Amerika, Orta Amerika, Afrika ve Avustralya / Pasifik gibi pek çok bölgede yüksek hızlı hizmetler hala mevcut değildir ve yalnızca Kuzey Amerika'da ve BDT'de sınırlı bir seviyede uygulanmaktadır. Çin, bu açıdan önemli bir istisnadır, çünkü dünyanın en büyük hızlı tren raylı sistem ağını kısa sürede geliştirmeyi başarmıştır.

Şekil 1'de belirtildiği gibi demiryolu pazarında 2013 yılından bu yana en yüksek büyüme anahat raylı sistem araçlarında ortaya çıkmıştır. Benzer bir büyüme oranının 2019-2021 için de süreceği tahmin edilerek yine aynı dönemde yıllık demiryolu piyasasının yaklaşık 122 milyar $€$ düzeyine ulaşacağı tahmin edilmektedir [6].

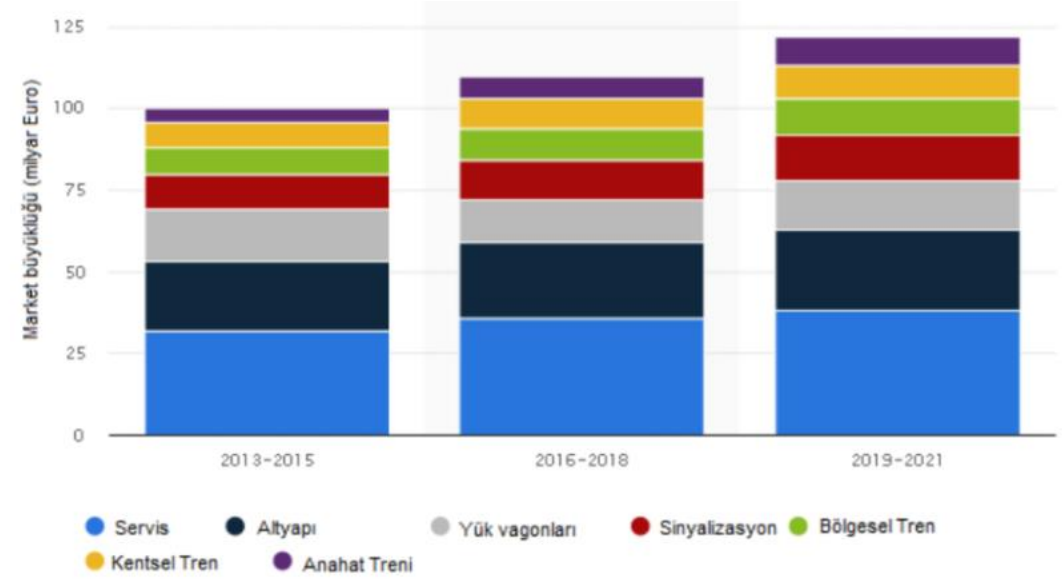

Şekil 1. Küresel demiryolu pazarının, 2013-2015'ten 2019-2021'e hizmet alanlarına göre dağılımı [6]

Demiryollarıyla yolcu taşımacılığında (yolcu-km) Avrupa'da, 2010 yılına göre 2030 yılında \% 50, 2050 yılında ise \% 100 oranında artış olacağı tahmin edilmektedir. Demiryoluyla yük 
taşımacılığının (ton-km) 2030 yılında karayolu yük taşımacılığı seviyesine ulaşacağı, 2050 yılında ise karayolu yük taşımacılığını yaklaşık \% 50 oranında geçeceği ön görülmektedir [7].

Ülkemizde demiryolu sektörünün gelişimi Osmanlı'nın son dönemlerine denk gelen 18. yy.'da başlamış; siyasi, ekonomik ve askeri sebeplerden ötürü önemli bir yere haiz olmuştur. Türkiye Cumhuriyeti'nin kurulmasının ardından demiryollarına bahşedilen önem çok daha artmış, ülkemizin pek çok noktasında demiryolu hatları inşa edilmeye başlamıştır. 1940'lı yıllara gelindiğindeyse kimi gerekçelerle, -dünya genelinde olduğu gibi- ülkemizde de demiryolu yatırımları yavaşlamışır.

Son yarım asırdır Dünyada yaşanan eğilimlere paralel olarak, Türkiye'nin demiryolu politikalarında bir değişiklik yaşanmış olup, 1950'li yıllardan itibaren neredeyse durma aşamasına gelen demiryolu yatırımlarına önem verilmeye başlanmıştır [8]. Hızlı tren, yüksek hızlı tren, kent içi raylı ulaşım ve metro sayılarında hızlı bir artış yaşanmış̧ır. Bu gibi gelişmelere bağlı olarak demiryolu araları ve komponentleri alanında Türkiye'nin ihracat ve ithalat rakamlarında pozitif bir ivme göze çarpmaktadır. Diğer taraftan 2017 yılında metro, hafif raylı sistem ve tramvay üretimi yapacak olan kamu kurum ve kuruluşları, belediyeler ve il özel idarelerine, üretimde en az \%51 yerli ürün kullanılması şartı getirilmesi de Yerli malı kullanım oranını yüzde 51'e çıkaran genelgesi ile $\% 51$ yerlilik oranı yerli firmalara büyük firsatlar sunmuş ulusal sektöre canlılık getirmiştir [11]. Aşağıda Türkiye'nin 2014-2018 yılları arasında ithalat ve ihracatının ulaştığı rakamlar görülmektedir.

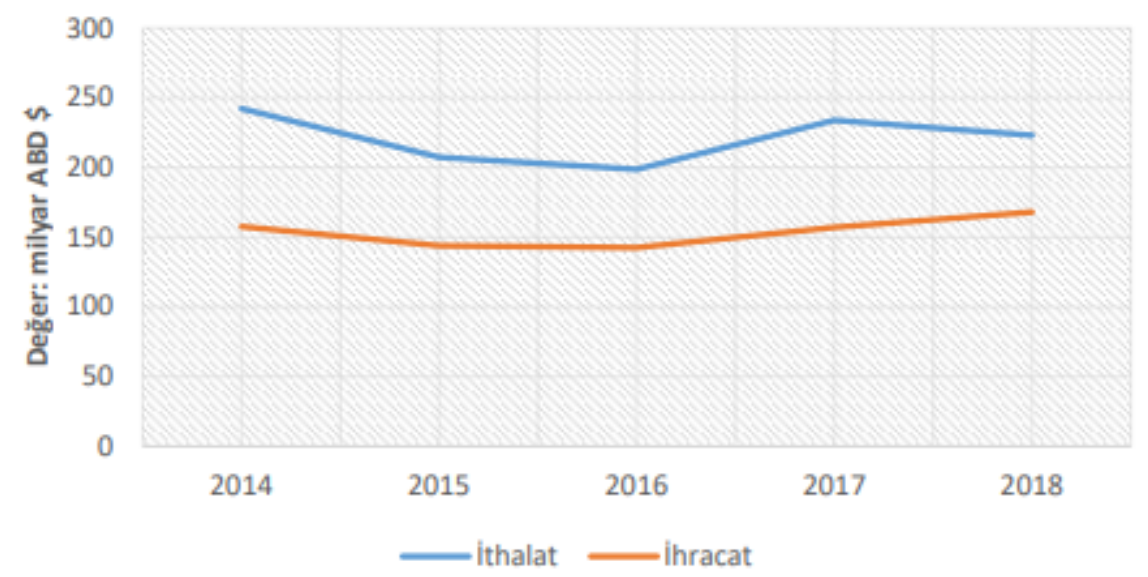

Şekil 2. 2014-2018 Türkiye ithalat ve ihracat tutarı değerleri değişimi eğrisi (milyar \$) [10]

Günümüze kadar yaşanan gelişmelerin yanı sıra Türkiye Ulaşım ve İletişim Stratejisinde yer alan aşağıdaki türde büyük projelerin hayata geçirilmesi sektörü önemli ölçüde etkileyecektir. Bunlar [12];

i. Halihazırdaki demiryolu ağının 800 km'lik bölümünün çift hat haline getirilmesi, $10.000 \mathrm{~km}$ yeni yüksek hızlı demiryolu hattı inşa edilmesi,

ii. $\quad 5.000 \mathrm{~km}$ yeni konvansiyonel demiryolu hattının faaliyete geçirilmesi,

iii. $\quad 8.000 \mathrm{~km}$ hattın elektrifikasyonunun tamamlanmas1,

iv. Tüm demiryolu hatlarının sinyalli hale getirilmesi amacıyla $8.000 \mathrm{~km}$ 'lik hattın sinyalizasyonunun bitirilmesi,

v. Standartların arttırılması amaciyla her yıl en az $500 \mathrm{~km}$ demiryolu hattının yenilenmesi, fabrika, OSB, liman gibi bölgelerle demiryolu bağlantılarının hazır edilmesi amacıyla 40 iltisak hattının inşa edilip faaliyete geçirilmesi,

vi. Mevcut durumdaki çeken ve çekilen araç parkının yenilenmesi için 180 YHT Seti, 300 dizel ve elektrikli lokomotif, 120 elektrikli set (EMU), 24 dizel set (DMU), 8.000 yük ve yolcu vagonu temin edilmesidir. 
Günümüzde şehir içi toplu taşımacılıkta kullanılan raylı ulaşım sistemleri; tramvaylar, hafif raylı sistemler, banliyö trenler, metrolar, manyetik raylı tren sistemleri (MAGLEV) ve üst yollu elektrikli bir toplu taşımacılık sistemi olan monoraydan meydana gelmektedir. Bunlardan ilk dört sistem ülkemizin farklı şehirlerinde etkin bir şekilde kullanılmaktadır.

Hafif raylı sistemler, temelde klasik tramvayın daha modern ve evrim geçirmiş hali olarak tanımlanabilir. Hafif raylı taşımacılık sisteminde, tek araba şeklinde veya kısa dizi olarak işletilebilen yükseltilmiş yollarda veya yer seviyesinde yollarda, diğer ulaşım modlarından ayrı bir şekilde kendine ait özel bir yolu olan, şehir içi elektrikli toplu ulaşım sistemidir. Genellikle nüfus artışlarının sınırlı kaldığı yapılaşmış çevre bölgelerde sık ve etkin bir şekilde kullanılmaktadır. Bir sürücü tarafindan sinyalizasyon sistemine sahip olarak kullanılan, her 600$1000 \mathrm{~m}$ arası mesafede özel istasyonlarda yolcu indirip bindiren, ortalama hızları $60-80 \mathrm{~km} / \mathrm{saat}$ ile kendine ait özel hatlarda işletilen raylı toplu ulaşım sistemleridir. Hafif raylı sistemlerin saatlik yolcu kapasiteleri yaklaşık 10.000- 20.000 kişi arasında değişiklik göstermektedir [13].

\section{Metot}

Bu çalışmada Türkiye demiryolu araçları, tramvaylar ve komponentleri sektörünün uluslararası rekabet gücünü ampirik olarak analiz etmek amaçlanmıştır. Rekabet gücünün ölçülmesine yönelik birçok yaklaşım bulunmakta ve bunlar içinde en sık kullanılan ve bu alanda önde gelen yöntemlerin başında "Açıklanmış Karşılaştırmalı Üstünlükler" yöntemi bulunmaktadır. Bu kapsamda Balassa ve Vollrath tarafindan ortaya koyulan endeksler benimsenmiştir. Bunun sebebi, Ricardo'ya ait [14] “Karşılaştırmalı Üstünlükler Teorisi”ne ve "Heckscher-Ohlin Teorisi" gereğince [15,16] -uygulamada- mukayeseli üstünlüklerin belirlenmesi oldukça zordur. $\mathrm{Bu}$ durumun nedeninin ticaret öncesi nispi fiyatların bilinmemesi olduğu söylenebilir. Balassa ticaret öncesi fiyatlara ulaşılamadığı durumlarda, ticaret sonrası ortaya çıkacak verilerin gözlemlenmesiyle de karşılaştırmalı üstünlüğün 'açıklanmasının' mümkün olabileceğini savunmuştur [8].

Açıklanmış Karşılaştırmalı Üstünlükler yönteminde ülkelerin belirlenen ürünlerin göreli ihracat performansları değerlendirilmektedir. Liesner Açıklanmış Karşılaştırmalı Üstünlükler yöntemini ileri süren ilk ekonomisttir [17] ancak yöntemi daha da geliştiren ise ekonomist Balassa'dır. Uygulamaya bakıldığında da daha çok Balassa'nın, “Açıklanmış Karşılaştırmalı Üstünlükler Endeksi" ya da "Balassa Endeksi" şeklinde bilinmekte olan endeks kullanılmaktadır. Balassa endeksi (RCA, BI) yalnızca ihracat değerlerini dikkate aldığı, ithalat değerlerini ihmal ettiğinden dolayı eleştiren Vollrath bu açığı kapatmak amacıyla yeni bir dizi endeks ortaya koymuştur [9].

Çalışmada, Türkiye demiryolu araçları, tramvaylar ve komponentleri sektörünün dünya karşısındaki rekabet gücünü analiz etmek amacıyla Açıklanmış Karşılaştırmalı Üstünlükler Endeksi (Balassa Endeksi) (RCA, BI), Vollrath tarafindan geliştirilmiş iki endeks olan Nispi Ticaret Avantajı Endeksi (RTA) ve Açıklanmış Rekabet Üstünlüğ̈̈ Endeksi (RC) kullanılmıştır. Üç endekse uygulanan veriler yorumlanarak, her bir endeks sonucu birbirleriyle karşılaştırılmıştır.

Balassa Endeksi'nin (RCA) formülü ve ayrıca formüldeki değişkenler aşağıda belirtilmiştir.

$\mathrm{RCA}=(\mathrm{Xij} / \mathrm{Xit}) /(\mathrm{Xwj} / \mathrm{Xwt})$

Xij: i ülkesi tarafından gerçekleştirilen j malı ihracatını,

Xit: i ülkesi tarafından gerçekleştirilen toplam ihracatı,

Xwj: Dünya ülkeleri tarafından gerçekleştirilen j malı ihracatını,

Xwt: Dünya ülkeleri tarafından gerçekleştirilen toplam ihracatı göstermektedir. 
Sonucun 1'den küçük değerde olması, ülkedeki ilgili üründe karş1laştırmalı üstünlük açısından dezavantajlı durumda olduğunu, 1'den büyük değerde olması ise ülkedeki o ürünün karşılaştırmalı üstünlüğe sahip olduğunu göstermektedir. Diğer taraftan endeksin ithalat verilerini kapsayan revize edilmiş haliyse şu şekildedir:

$\mathrm{RCA}=\operatorname{Ln}(\mathrm{Xij} / \mathrm{Xit}) /(\mathrm{Mij} / \mathrm{Mit}) \times 100$

Xij: i ülkesi tarafından gerçekleştirilen j malı ihracatını,

Xit: i ülkesi tarafından gerçekleştirilen toplam ihracatı,

Mij: i ülkesi tarafindan gerçekleştirilen j malı ithalatını,

Mit: i ülkesi tarafından gerçekleştirilen toplam ithalatını göstermektedir.

RCA'lara göre sektörün rekabet gücünün analizi yapılırken:

RCA $>50$ ise ilgili sektörde rekabet gücünün fazla,

$\mathrm{RCA}<-50$ ise ilgili sektörde rekabet gücünün az,

$-50<\mathrm{RCA}<50$ ise ilgili sektörde rekabet gücünün sınırda olduğu belirtilmektedir [18].

Ardından Vollrath, Nispi İthalat ve Nispi İhracat endeksleri vasıtasıyla Nispi Ticaret Avantaj1 (RTA) endeksini geliştirerek, bunu Nispi İhracat Avantaj1 Endeksi RXA=[(Xij / (Xit-Xij)] / $[(X w j-X i j) /(X w t-X i t)]$ formülüyle hesaplamaktadır. Formülde bulunan değerler Balassa endeksinde kullanılan değerlerdir.

Nispi İthalat Avantaji Endeksi RMA=[(Mij / (Mit-Mij)] / [(Mwj-Mij) / (Mwt-Mit)] formülü vasıtasıyla hesaplanmaktadır. Formülde;

Mij: i ülkesi tarafından gerçekleştirilen j malı ithalatını,

Mit: i ülkesi tarafından gerçekleştirilen toplam ithalatı,

Mwj: Dünya ülkeleri tarafından gerçekleştirilen j malı ithalatını,

Mwt: Dünya ülkeleri tarafından gerçekleştirilen toplam ithalatı göstermektedir.

Böylece, Nispi Ticaret Avantajı Endeksi RTA= RXA-RMA formülüyle bulunmaktadır.

RTA >0 çıkması durumunda ülke üründe (sektörde) rekabet gücüne sahip olup,

RTA $<0$ çıkması durumunda ise ülke üründe (sektörde) rekabet gücüne sahip değildir [19]

Çalışmada değerlendirilen son endeks ise Açıklanmış Rekabet Üstünlüğü Endeksi (RC) aşağıdaki formül vasıtasıyla bulunmaktadır.

$\mathrm{RC}=\operatorname{lnRXA}-\ln R M A$

Buna göre bulunan endeks, RC>0 durumunda söz konusu üründe karşılaştırmalı avantaj,

$\mathrm{RC}<0$ bulunması durumunda söz konusu üründe karşılaştırmalı dezavantaj olduğu ortaya konmaktadır [18].

Çalışma, 2010-2020 yıllarını kapsamaktadır. Dış ticaret verileri Uluslararası Ticaret Merkezi Veri Tabanı (Trade Map)'ndan elde edilmiştir. Uluslararası Harmonize Sistem Ürün Sinıflandırmasındaki (Harmonized System Commodity Classification Codes) raylı sistem sektörüne ait olan ürün kodu 86 olup, adı; Demiryolu araçları, tramvaylar ve komponentleri olarak tanımlanmaktadır. 
Tablo 1. Sektöre ait GTİP kodları

\begin{tabular}{ll}
\hline 86 & Demiryolu araçları, tramvaylar ve Komponentleri \\
8601 & $\begin{array}{l}\text { Elektrikli lokomotifler (elektrik enerjisini dışarıdan alanlar veya elektrik akümülatörlü } \\
\text { olanlar) }\end{array}$ \\
8602 & $\begin{array}{l}\text { Diğer lokomotifler; lokomotif tenderler } \\
8603\end{array}$ \\
Kendinden hareketli demiryolu veya tramvay vagonları \\
8604 & $\begin{array}{l}\text { Demiryolu hat bakım ve servis taşıtları (atölye-vinçli vagonlar, balast sıkıştırma vagonları, } \\
\text { hat döşeyiciler vb) }\end{array}$ \\
8605 & $\begin{array}{l}\text { Kendinden hareketli olmayan demiryolu veya tramvay yolcu vagonları; bagaj furgonları, } \\
\text { diğer demiryolu ve tramvay vagonları }\end{array}$ \\
8606 & Kendinden hareketli olmayan yük taşımaya mahsus demiryolu veya tramvay vagonları \\
8607 & $\begin{array}{l}\text { Demiryolu-tramvay için sabit malzeme; mekanik işaret, emniyet, trafik kontrol-kumanda } \\
\text { cihazları; bunların aksam-parçaları }\end{array}$ \\
8608 & Demiryolu taşıtlarının veya tramvayların aksam ve parçaları \\
8609 & Bir veya daha fazla taşıma şekline göre özel olarak yapılmış ve donatılmış konteynerler \\
\hline
\end{tabular}

\section{Bulgular}

Türkiye demiryolu araçları, tramvaylar ve komponentleri sektörünün rekabet gücüne yönelik bulunan endeks değerlerine Tablo 2'de yer verilmiştir. Açıklanmış karşılaştırmalı üstünlükler endeks değerinin 1'den küçük olması ilgili sektörde mukayeseli dezavantaja sahip olduğunu, 1 veya 1'den büyük olması ise ilgili sektörde mukayeseli üstünlüğe sahip olduğunu göstermektedir. 2010-2020 döneminde demiryolu araçları, tramvaylar ve komponentleri sektörümüz için karşılaştırmalı üstünlük değerine sahip olmadığını görebiliriz. Ancak 2016'dan bu yana endeks değerinin giderek artıyor olması sektörün karşılaştırmalı üstünlüğünün yükseleceğine işarettir. 2013 yılında endeks değeri yapılan ihracatlarla en yüksek değerine ulaşmıştır.

Endeksin ithalat verilerini de içeren revize edilmiş halini incelediğimizde ise sektörümüzün 2010-2020 arasında hiç rekabet gücü yüksek olmamış. Fakat 2019 yılında indeks -50 ile +50 arasında $-11,72$ değerini alarak sektörümüzün rekabet gücünün sınırda olduğunu görebiliriz. 2019 dışındaki bütün yıllarda sektörün rekabet gücü düşüktür. Ayrıca 2016-2019 periyodunda endeksin sürekli artması olumlu bir gelişme olmakla beraber önümüzdeki yıllarda sektörün rekabet gücünün daha da yükselmesi beklenmektedir.

Nispi Ticaret Avantajı endeksi incelendiğinde yine demiryolu araçları, tramvaylar ve komponentleri sektörü 2010-2020 periyodunda rekabet gücüne sahip değildir. İncelenen dönem içerisinde Nispi Ticaret Avantaj1 2019 yılında -0,19'la en yüksek değere ulaşmıştır. Son yıllarda endeks değeri sıfıra yaklaşmış ve rekabet gücünde bir artış olduğu göze çarpmaktadır.

Son olarak Açıklanmış Rekabet Üstünlüğü Endeksi incelendiğinde ise raylı sistemler sektöründeki mallarda karşılaştırmalı dezavantaj söz konusudur. Söz konusu dönemde 2013 yılında yapılan ihracatla artışa geçen rekabet üstünlüğü endeksi tekrar düşmeye başlamış ve son y1llarda bir artış trendine girmiştir.

Fakat 2020 y1lında pandeminin ihracat ve ithalata olan negatif etkisiyle endeks değerlerinde düşüş gözlenmiştir. Önümüzdeki yıllarda pandemi etkisinin azalmasıyla endeks değerlerinde tekrar yükseliş trendine girmesi beklenmektedir. 
Tablo 2. 86-Demiryolu araçları, tramvaylar ve komponentleri genel analizi

\begin{tabular}{ccccc}
\hline Yıllar & $\begin{array}{c}\text { Açıklanmış } \\
\text { Karşılaştırılmış } \\
\text { Üstünlükler } \\
\text { (RCA) }\end{array}$ & $\begin{array}{c}\text { İthalat verileriyle } \\
\text { Açılanmış } \\
\text { Karşılaştırılmış } \\
\text { Üstünlükler (RCA) }\end{array}$ & $\begin{array}{c}\text { Nispi Ticaret } \\
\text { Avantajı } \\
\text { (RTA) }\end{array}$ & $\begin{array}{c}\text { Açıklanmış } \\
\text { Rekabet } \\
\text { Üstünlüğü } \\
\text { Endeksi (RC) }\end{array}$ \\
\hline 2010 & 0,07 & $-295,43$ & $-1,62$ & $-3,24$ \\
2011 & 0,36 & $-128,91$ & $-1,43$ & $-1,61$ \\
2012 & 0,35 & $-102,55$ & $-0,88$ & $-1,27$ \\
2013 & 0,57 & $-65,26$ & $-0,81$ & $-0,89$ \\
2014 & 0,42 & $-96,74$ & $-1,01$ & $-1,24$ \\
2015 & 0,28 & $-98,30$ & $-0,72$ & $-1,27$ \\
2016 & 0,17 & $-177,48$ & $-1,09$ & $-1,99$ \\
2017 & 0,26 & $-119,16$ & $-0,84$ & $-1,46$ \\
2018 & 0,22 & $-56,52$ & $-0,32$ & $-0,89$ \\
2019 & 0,47 & $-11,72$ & $-0,19$ & $-0,35$ \\
2020 & 0,43 & $-85,40$ & $-0,91$ & $-1,13$ \\
\hline
\end{tabular}

Tablo 3'de Türkiye demiryolu araçları, tramvaylar ve komponentleri sektörünün, Balassa Endeksi (RCA)'ne göre hesaplanmış karşılaş̧ırmalı üstünlük endeks değerlerine yer verilmektedir. Yapılan hesaplama sonuçları değerlendirildiğinde açıklanmış karşılaştırmalı üstünlüğü yüksek düzeyde çıkan alt sektörler, 2013-2014 yıllarında;

- 8602-Diğer lokomotifler; lokomotif tenderler,

- 2011-2014 yılları arasinda,

- 8603-Kendinden hareketli demiryolu veya tramvay vagonları,

2013 ve 2015 y1llarında;

- 8605-Kendinden hareketli olmayan demiryolu veya tramvay yolcu vagonlar1; bagaj furgonları, diğer demiryolu ve tramvay vagonları,

2017-2018-2019 y1llarında ise,

- 8608-Demiryolu-tramvay için sabit malzeme; mekanik işaret, emniyet, trafik kontrolkumanda cihazları; bunların aksam-parçalarıdır.

Tablo 3. Açıklanmış karşılaştırılmış üstünlükler (RCA)

\begin{tabular}{lllllllllllll}
\hline $\begin{array}{c}\text { GTIP } \\
\text { Kodu }\end{array}$ & 2010 & 2011 & 2012 & 2013 & 2014 & 2015 & 2016 & 2017 & 2018 & 2019 & 2020 & $\begin{array}{c}2010- \\
\text { 20 Ort }\end{array}$ \\
\hline 8601 & 0,00 & 0,00 & 0,00 & 0,01 & 0,03 & 0,01 & 0,01 & 0,03 & 0,03 & 0,02 & 0,00 & 0,01 \\
8602 & 0,01 & 0,00 & 0,36 & 1,02 & 1,33 & 0,00 & 0,03 & 0,00 & 0,00 & 0,02 & 0,69 & 0,31 \\
8603 & 0,01 & 2,51 & 1,87 & 2,10 & 1,65 & 0,92 & 0,26 & 0,79 & 0,35 & 0,62 & 0,13 & 1,02 \\
8604 & 0,07 & 0,00 & 0,00 & 0,37 & 0,82 & 0,19 & 0,00 & 0,00 & 0,49 & 0,18 & 0,22 & 0,21 \\
8605 & 0,06 & 0,05 & 0,00 & 3,63 & 0,00 & 1,77 & 0,01 & 0,00 & 0,00 & 0,02 & 0,30 & 0,53 \\
8606 & 0,01 & 0,09 & 0,02 & 0,00 & 0,00 & 0,01 & 0,01 & 0,02 & 0,01 & 0,05 & 0,68 & 0,08 \\
8607 & 0,11 & 0,09 & 0,10 & 0,15 & 0,21 & 0,21 & 0,29 & 0,33 & 0,41 & 0,71 & 0,63 & 0,30 \\
8608 & 0,23 & 0,62 & 0,23 & 0,59 & 0,45 & 0,84 & 0,92 & 1,28 & 1,20 & 1,20 & 0,29 & 0,72 \\
8609 & 0,08 & 0,08 & 0,09 & 0,10 & 0,07 & 0,09 & 0,06 & 0,05 & 0,06 & 0,16 & 0,23 & 0,10 \\
\hline
\end{tabular}

Tablo 4'de Türkiye demiryolu araçları, tramvaylar ve komponentleri sektörünün Balassa Endeksi (BI, RCA) ithalat verilerine göre hesaplanmış karşılaştırmalı üstünlük endeks değerleri 
yer almaktadır. Hesaplama sonuçlarına göre açıklanmış karşılaştırmalı üstünlüğü yüksek düzeyde çıkan alt sektörler;

2012-2014 y1llarında,

- 8602-Diğer lokomotifler; lokomotif tenderler,

2014 ve 2018 yıllarında,

- 8604- Demiryolu hat bakım ve servis taşıtları (atölye-vinçli vagonlar, balast sıkıştırma vagonları, hat döşeyiciler vb),

2010-2011-2013-2015-2016 yıllarında,

- 8605-Kendinden hareketli olmayan demiryolu veya tramvay yolcu vagonlar1;bagaj furgonları, diğer demiryolu ve tramvay vagonları,

2019 yılinda,

- 8601-Elektrikli lokomotifler (elektrik enerjisini dışarıdan alanlar veya elektrik akümülatörlü olanlar) ve

- 8606-Kendinden hareketli olmayan yük taşımaya mahsus demiryolu veya tramvay vagonlarıdır.

2020 y1lında ise,

- 8602-Diğer lokomotifler; lokomotif tenderler,

- 8604-Demiryolu hat bakım ve servis taşıtları (atölye-vinçli vagonlar, balast sıkıştırma vagonları, hat döşeyiciler vb),

- 8606-Kendinden hareketli olmayan yük taşımaya mahsus demiryolu veya tramvay vagonlar1,

- 8609-Bir veya daha fazla taşıma şekline göre özel olarak yapılmış ve donatılmış konteynerlerdir.

Tablo 4. İthalat verileriyle açıklanmış karşılaştırılmış üstünlükler (RCA)

\begin{tabular}{|c|c|c|c|c|c|c|c|c|c|c|c|c|}
\hline $\begin{array}{l}\text { GTIP } \\
\text { Kodu }\end{array}$ & 2010 & 2011 & 2012 & 2013 & 2014 & 2015 & 2016 & 2017 & 2018 & 2019 & 2020 & $\begin{array}{c}2010-20 \\
\text { Ort. }\end{array}$ \\
\hline 8601 & $\begin{array}{c}\text { Değer } \\
\text { yok }\end{array}$ & $-371,64$ & $-335,44$ & $-705,62$ & $-547,55$ & $-614,70$ & $-213,96$ & $-157,68$ & $-54,75$ & 216,59 & $\begin{array}{l}\text { Değer } \\
\text { yok }\end{array}$ & $-309,42$ \\
\hline 8602 & $-277,65$ & $\begin{array}{l}\text { Değer } \\
\text { yok }\end{array}$ & 171,56 & 205,67 & 10,09 & $\begin{array}{l}\text { Değer } \\
\text { yok }\end{array}$ & $-237,42$ & $\begin{array}{c}\text { Değer } \\
\text { yok }\end{array}$ & $\begin{array}{l}\text { Değer } \\
\text { yok }\end{array}$ & $-383,17$ & 193,32 & $-45,37$ \\
\hline 8603 & $-647,78$ & $-122,58$ & $-87,52$ & $-56,67$ & $-97,65$ & $-90,61$ & $-277,46$ & $-168,28$ & $-122,92$ & $-53,42$ & $-358,14$ & $-189,37$ \\
\hline 8604 & $-163,09$ & $-745,18$ & $-826,12$ & $-198,60$ & 83,50 & $-166,62$ & $\begin{array}{c}\text { Değer } \\
\text { yok }\end{array}$ & $-457,52$ & 52,42 & $-200,60$ & 59,03 & $-256,28$ \\
\hline 8605 & 85,62 & 88,45 & $\begin{array}{l}\text { Değer } \\
\text { yok }\end{array}$ & 659,21 & $\begin{array}{l}\text { Değer } \\
\text { yok }\end{array}$ & 709,18 & 82,97 & $-293,06$ & $-46,64$ & $-426,65$ & $-366,48$ & 54,73 \\
\hline 8606 & $-291,72$ & $-102,26$ & $-126,77$ & $-333,80$ & $-485,24$ & $-183,47$ & $-178,87$ & $-14,45$ & $-58,56$ & 556,65 & 426,14 & $-72,03$ \\
\hline 8607 & $-170,57$ & $-190,56$ & $-167,51$ & $-132,87$ & $-98,82$ & $-95,58$ & $-101,91$ & $-44,31$ & $-42,75$ & 22,50 & 12,20 & $-91,84$ \\
\hline 8608 & $-278,63$ & $-54,67$ & $-90,50$ & $-171,82$ & $-178,37$ & $-89,93$ & $-31,43$ & 29,08 & 16,87 & 23,26 & $-26,39$ & $-77,50$ \\
\hline 8609 & 11,06 & 51,81 & 41,21 & 56,65 & $-56,24$ & 78,22 & $-20,28$ & $-63,75$ & $-46,47$ & 9,78 & 76,63 & 12,60 \\
\hline
\end{tabular}

RTA endeksine göre ortaya çıkan sonuçlara göre, Türkiye demiryolu araçları, tramvaylar ve komponentleri sektörünün dünya karşısında nispi ticaret avantajına sahip olduğu alt sektörler, Tablo 5'de görüldüğü gibi 2019 yılında,

- 8601- Elektrikli lokomotifler (elektrik enerjisini dışarıdan alanlar veya elektrik akümülatörlü olanlar)

- 8606-Kendinden hareketli olmayan yük taşımaya mahsus demiryolu veya tramvay vagonları,

- 8607-Demiryolu taşıtlarının veya tramvayların aksam ve parçaları,

- 8608-Demiryolu-tramvay için sabit malzeme; mekanik işaret, emniyet, trafik kontrolkumanda cihazları; bunların aksam-parçalarıdır. 
20102015 yılları arasinda,

- 8605-Kendinden hareketli olmayan demiryolu veya tramvay yolcu vagonlar1; bagaj furgonları, diğer demiryolu ve tramvay vagonları alt sektörü nispi ticaret avantajına sahiptir.

2017-2019 y1lları arasinda

- 8608-Demiryolu-tramvay için sabit malzeme; mekanik işaret, emniyet, trafik kontrolkumanda cihazları; bunların aksam-parçaları alt sektörü,

2020 yılinda,

- 8602-Diğer lokomotifler; lokomotif tenderler,

- 8604-Demiryolu hat bakım ve servis taşıtları (atölye-vinçli vagonlar, balast sıkıştırma vagonları, hat döşeyiciler vb),

- 8606-Kendinden hareketli olmayan yük taşımaya mahsus demiryolu veya tramvay vagonları,

- 8607-Demiryolu taşıtlarının veya tramvayların aksam ve parçaları nispi ticaret avantajına sahip olarak dikkat çekmektedir.

Tablo 5. Nispi ticaret avantaj1 (RTA)

\begin{tabular}{ccccccccccccc}
\hline GTIP & 2010 & 2011 & 2012 & 2013 & 2014 & 2015 & 2016 & 2017 & 2018 & 2019 & 2020 & $\begin{array}{c}2010- \\
\text { Kodu Ort. }\end{array}$ \\
\hline 8601 & $-0,02$ & $-0,02$ & $-0,03$ & $-7,54$ & $-5,63$ & $-3,17$ & $-0,11$ & $-0,09$ & $-0,02$ & 0,02 & 0,00 & $-1,51$ \\
8602 & $-0,18$ & $-0,28$ & 0,28 & 0,89 & $-0,22$ & $-2,03$ & $-0,35$ & $-0,17$ & $-0,08$ & $-0,95$ & 0,58 & $-0,23$ \\
8603 & $-8,01$ & $-9,65$ & $-2,83$ & $-1,90$ & $-3,18$ & $-1,35$ & $-4,19$ & $-3,34$ & $-0,93$ & $-0,46$ & $-3,70$ & $-3,59$ \\
8604 & $-0,26$ & $-3,06$ & $-5,59$ & $-2,35$ & 0,54 & $-0,81$ & $-2,14$ & $-0,24$ & 0,21 & $-1,03$ & 0,10 & $-1,33$ \\
8605 & 0,04 & 0,03 & 0,00 & 3,71 & 0,00 & 1,78 & 0,00 & $-0,12$ & 0,00 & $-1,23$ & $-18,78$ & $-1,32$ \\
8606 & $-0,14$ & $-0,18$ & $-0,05$ & $-0,15$ & $-0,95$ & $-0,11$ & $-0,16$ & $-0,02$ & $-0,02$ & 0,05 & 0,66 & $-0,10$ \\
8607 & $-0,50$ & $-0,52$ & $-0,43$ & $-0,42$ & $-0,35$ & $-0,31$ & $-0,44$ & $-0,15$ & $-0,19$ & 0,15 & 0,08 & $-0,28$ \\
8608 & $-3,70$ & $-0,55$ & $-0,36$ & $-2,93$ & $-2,38$ & $-1,25$ & $-0,18$ & 0,44 & 0,17 & 0,12 & $-1,39$ & $-1,09$ \\
8609 & $-0,18$ & $-0,12$ & $-0,10$ & $-0,07$ & $-0,26$ & $-0,03$ & $-0,08$ & $-0,24$ & $-0,23$ & $-0,16$ & $-0,06$ & $-0,14$ \\
\hline
\end{tabular}

Tablo 6'da Türkiye demiryolu araçları, tramvaylar ve komponentleri sektörünün dünya karşısındaki açıklanmış rekabet üstünlüğü $(\mathrm{RC})$ endeks değerleri verilmiştir.

Tablo 6. Açıklanmış rekabet üstünlüğü endeksi (RC)

\begin{tabular}{cccccccccccccc}
\hline $\begin{array}{c}\text { GTIP } \\
\text { Kodu }\end{array}$ & 2010 & 2011 & 2012 & 2013 & 2014 & 2015 & 2016 & 2017 & 2018 & 2019 & 2020 & $\begin{array}{c}2010- \\
20 \text { Ort. }\end{array}$ \\
\hline 8601 & $\begin{array}{c}\text { Değer } \\
\text { yok }\end{array}$ & $-3,48$ & $-3,17$ & $-6,80$ & $-5,38$ & $-6,14$ & $-2,21$ & $-1,47$ & $-0,49$ & 2,55 & $\begin{array}{c}\text { Değer } \\
\text { yok }\end{array}$ & $-2,95$ \\
8602 & $-2,76$ & $\begin{array}{c}\text { Değer } \\
\text { yok }\end{array}$ & 1,46 & 2,06 & $-0,16$ & $\begin{array}{c}\text { Değer } \\
\text { yok }\end{array}$ & $\begin{array}{c}-2,69 \\
\text { Değer } \\
\text { yok }\end{array}$ & $\begin{array}{c}\text { Değer } \\
\text { yok }\end{array}$ & $-3,69$ & 1,91 & $-0,55$ \\
8603 & $-6,70$ & $-1,57$ & $-0,92$ & $-0,64$ & $-1,07$ & $-0,91$ & $-2,83$ & $-1,65$ & $-1,30$ & $-0,56$ & $-3,54$ & $-1,97$ \\
8604 & $-1,60$ & $-7,36$ & $-8,22$ & $-2,00$ & 1,10 & $-1,65$ & $\begin{array}{c}\text { Değer } \\
\text { yok }\end{array}$ & $-4,56$ & 0,57 & $-1,93$ & 0,61 & $-2,51$ \\
8605 & 0,87 & 1,02 & $\begin{array}{c}\text { Değer } \\
\text { yok }\end{array}$ & 6,63 & $\begin{array}{c}\text { Değer } \\
\text { yok }\end{array}$ & 6,86 & 0,16 & $-3,28$ & $-1,23$ & $-4,32$ & $-4,15$ & 0,28 \\
8606 & $-3,11$ & $-1,14$ & $-1,48$ & $-3,73$ & $-5,60$ & $-2,80$ & $-2,61$ & $-0,65$ & $-1,15$ & 4,92 & 3,53 & $-1,26$ \\
8607 & $-1,74$ & $-1,89$ & $-1,66$ & $-1,32$ & $-0,96$ & $-0,91$ & $-0,91$ & $-0,37$ & $-0,39$ & 0,24 & 0,14 & $-0,89$ \\
8608 & $-2,86$ & $-0,63$ & $-0,94$ & $-1,78$ & $-1,84$ & $-0,91$ & $-0,18$ & 0,42 & 0,15 & 0,11 & $-1,76$ & $-0,93$ \\
8609 & $-1,17$ & $-0,91$ & $-0,75$ & $-0,51$ & $-1,50$ & $-0,32$ & $-0,87$ & $-1,77$ & $-1,57$ & $-0,72$ & $-0,23$ & $-0,94$ \\
\hline
\end{tabular}


2020 y1lı itibariyle Türkiye'nin dünya karşısında açıklanmış rekabet üstünlüğüne sahip olduğu alt sektörler;

- 8602-Diğer lokomotifler; lokomotif tenderler,

- 8604-Demiryolu hat bakım ve servis taşıtları (atölye-vinçli vagonlar, balast sıkıştırma vagonları, hat döşeyiciler vb),

- 8606-Kendinden hareketli olmayan yük taşımaya mahsus demiryolu veya tramvay vagonları, 8607-Demiryolu taşıtlarının veya tramvayların aksam ve parçaları,

- 8607- Demiryolu taşıtlarının veya tramvayların aksam ve parçaları,

2010-2016 y1lları itibariyle,

- 8605-Kendinden hareketli olmayan demiryolu veya tramvay yolcu vagonlar1; bagaj furgonları, diğer demiryolu ve tramvay vagonları alt sektörünün açıklanmış rekabet üstünlüğünün oldukça yüksek olduğu görülmektedir ve en yüksek değere 2015 yılında ulaşılmıştır.

Çalışmada dört farklı yöntem kullanılmış olup bunlar; Balassa'nın Açıklanmış Karşılaştırmalı Üstünlükler Endeksi (Balassa Endeksi) (RCA, BI), ithalat verileri kullanılarak elde edilen Açıklanmış Karşılaştırmalı Üstünlükler Endeksi (RCA), Vollrath'ın Nispi Ticaret Avantajı Endeksi (RTA) ve yine Vollrath'ın Açıklanmış Rekabet Üstünlüğü Endeksi (RC)'dir. Ayrıca tablo 7'de Nispi Ticaret Avantajı, Balassa ve Açıklanmış Rekabet Üstünlügü endeks sonuçlarının karşılaştırılması özet halinde sunulmuştur. Ortaya çıkan her dört endeks değerleri de birbirleriyle uyumlu sonuçlar vermiştir. Değerlendirme sonuçlarına göre elde edilen bulgular şöyledir:

Balassa Endeksi'ne (RCA, BI) göre rekabet gücü yüksek olan dört haneli alt sektör,

- 8603-Kendinden hareketli demiryolu veya tramvay vagonlarıdır.

İthalat verileriyle hesaplanan Balassa Endeksine göre rekabet gücü yüksek, Nispi Ticaret Avantajı (RTA)'na sahip ve Açıklanmış Rekabet Üstünlüğü Endeksi (RC)'ne sahip alt sektör,

- 8605-Kendinden hareketli olmayan demiryolu veya tramvay yolcu vagonlar1; bagaj furgonları, diğer demiryolu ve tramvay vagonlarıdır.

Rekabet gücü en düşük olan dört haneli alt sektör,

- 8601-Elektrikli lokomotifler; elektrik enerjisini dışarıdan alanlar veya elektrik akümülatörlü olanlardir.

Rekabet gücü sinırda olan dört haneli alt sektör ise,

- 8609- Bir veya daha fazla taşıma şekline göre özel olarak yapılmış ve donatılmış konteynerlerdir. 
Tablo 7. Türkiye demiryolu araçları, tramvaylar ve komponentleri sektörü rekabet gücünün dört endeks (RCA, RCA İthalat, RTA, RC) değerlerine göre karşılaştırılması

\begin{tabular}{|c|c|c|c|c|c|c|c|c|}
\hline \multirow{2}{*}{$\begin{array}{l}\text { GTIP } \\
\text { Kodu } \\
8601\end{array}$} & \multicolumn{2}{|c|}{$\begin{array}{c}\text { Balassa Endeksi } \\
\text { (RCA) } \\
2010 / 2020 \\
\text { Ortalama }\end{array}$} & \multicolumn{2}{|c|}{$\begin{array}{c}\text { Açılklanmış } \\
\text { Karşılaştırılmış } \\
\text { Üstünlükler (RCA) } \\
\text { ithalat verileri ile } \\
\text { 2010/2020 Ortalama }\end{array}$} & \multicolumn{2}{|c|}{$\begin{array}{l}\text { Nispi Ticaret Avantaj1 } \\
\text { Endeksi (RTA) } \\
\text { 2010/2020 Ortalama }\end{array}$} & \multicolumn{2}{|c|}{$\begin{array}{l}\text { Açıklanmış Rekabet } \\
\text { Üstünlüğü Endeksi (RC) } \\
\text { 2010/2020 Ortalama }\end{array}$} \\
\hline & 0,01 & Değil & $-278,47$ & Düşük & $-1,51$ & Dezavantaj & $-2,95$ & Dezavantaj \\
\hline 8602 & 0,31 & Değil & $-45,37$ & Düşük & $-0,23$ & Dezavantaj & $-0,55$ & Dezavantaj \\
\hline 8603 & 1,02 & Sahip & $-189,37$ & Düşük & $-3,59$ & Dezavantaj & $-1,97$ & Dezavantaj \\
\hline 8604 & 0,21 & Değil & $-256,28$ & Düşük & $-1,33$ & Dezavantaj & $-2,51$ & Dezavantaj \\
\hline 8605 & 0,53 & Değil & 54,73 & Yüksek & $-1,32$ & Dezvantaj & 0,28 & Avantaj \\
\hline 8606 & 0,08 & Değil & $-72,03$ & Düşük & $-0,10$ & Dezavantaj & $-1,26$ & Dezavantaj \\
\hline 8607 & 0,30 & Değil & $-91,84$ & Düşük & $-0,28$ & Dezavantaj & $-0,89$ & Dezavantaj \\
\hline 8608 & 0,72 & Değil & $-77,50$ & Düşük & $-1,09$ & Dezavantaj & $-0,93$ & Dezavantaj \\
\hline 8609 & 0,10 & Değil & 12,60 & Sinırda & $-0,14$ & Dezavantaj & $-0,94$ & Dezavantaj \\
\hline
\end{tabular}

\section{Sonuç}

Türkiye demiryolu araçları, tramvaylar ve komponentleri sektörü rekabet gücünün Dünya ortalamalarına göre incelendiği bu çalışmada, araştırma yöntemi olarak açıklanmış karşılaştırmalı üstünlükler yöntemi kullanılmıştır. Söz konusu sektörünün rekabet gücü, dört haneli olarak toplam dokuz alt sektör özelinde; "Açıklanmış Karşılaştırmalı Üstünlükler Endeksi”, "İthalat Verileriyle Açıklanmış Karşılaştırmalı Üstünlükler Endeksi,", "Açıklanmış Rekabet Üstünlügü Endeksi" ve "Nispi Ticaret Avantajı Endeksi" olmak üzere dört farklı hesaplama yöntemi vasıtasıyla analiz edilmiştir. Bu dört farklı hesaplama yöntemi ayrı ayrı incelendiğinde ise elde edilen sonuçlar genellikle birbirleri ile uyumlu çıkmıştır.

Türkiye'de rekabet gücü sektörler yüksek arasında otomotiv, demir-çelik gibi sektörler yer almaktadır[20,22]. Maalesef demiryolu araçları sektörü henüz rekabetçi bir sektör değildir. Özellikle 11. Kalkınma Planında raylı sistem araçlarının öncelikli sektörler arasında kabul edilmesi sektörün rekabetçilik konusunda ilerleyeceğini göstermektedir.

Çalışmanın sonuçlarına göre, Türkiye demiryolu araçları, tramvaylar ve komponentleri sektörü içerisinde özellikle "8601- Elektrikli Lokomotifler..." ile "8609 - Bir veya daha fazla taşıma şekline göre özel olarak yapılmış ve donatılmış konteynerler" alt sektörlerinin rekabet gücünün zayıf olduğu tespit edilmiştir. Bunun ana nedeni, demiryolu araçları, tramvaylar ve komponentleri sektöründe yeterli ana ve yan sanayinin oluşmamış olmasıdır. Diğer taraftan sanayi kurumları, teknoparklar ve üniversiteler arasında demiryolu araçlarına yönelik iş birliklerinin zayıf olması ve ilgili tarafların yeterli fonları bulmada güçlük yaşamaları sebebiyle Ar\&Ge çalışmalarının yeterli düzeyde olmaması diğer bir neden olarak söylenebilir. Yine elektrikli lokomotifler sadece TÜRASAŞ tarafından devlet eliyle üretildiği için ve özel sektör üretici firmaları bu alanda yer almaması nedeniyle bir rekabet ortamı oluşmamaktadır.

Özel konteynerlerin üretimi özelinde ise bu türde üretimleri gerçekleştiren firmaların yeterli sayıda olmaması söylenebilir. Bunda da konteyner limancılığının Türkiye'de çok fazla gelişmemiş olması kök neden olarak gösterilebilir. 
Türkiye'deki raylı sistem araçları üreticileri sadece iç pazarı değil yurtdışı pazarlarını da hedeflemelidir. Son zamanlarda özellikle raylı sistem imalat sektörüne önemli teşvikler verilmektedir. Teşviklerin sürekliliği sağlanıp yurtdışı pazarlara giriş kapsamında da firmalara destekler verilmelidir. Diğer taraftan 11. Kalkınma Planı Raylı Sistem Araçlarında Yerli Üretim Çalışma Grubu Raporu'na göre [7] sürdürülebilir bir raylı sistem araçları (Demiryolu araçları, tramvaylar ve komponentleri) sektörü için ülkemiz ihracatının yıllık 300 milyon TL'nin üzerinde olması gerekmektedir. Bunu sağlamak için mevzuatta ve ilgili bakanlı̆̆ın yapılanmasında birtakım değişikliklere gidilebilir. Yapılabilecekler arasında Savunma Sanayi Başkanlığı'nda olduğu gibi raylı teknoloji ile ilgili sektöre yönelik bir "Yerlileştirme Başkanlığı" kurulmalı ve bu başkanlık vasıtasıyla belediyeler dahil tüm kamu ihalelerinde yerlileştirme programı (SIP) uygulanmalı ve denetlenmelidir.

8605-Kendinden hareketli olmayan demiryolu veya tramvay yolcu vagonları; bagaj furgonları, diğer demiryolu ve tramvay vagonları alt sektörünün diğer alt sektörlerle kıyaslandığında yüksek rekabet gücüne sahip olduğu göze çarpmaktadır. Bunun en önemli nedenlerinden biri vagon üretiminde özel sektörün rekabetçi ve kaliteli üretim seviyesine ulaşıp ihracat yapabilmesidir. Diğer önemli bir neden ise yurtdışından alınan vagonlara tip onay verilmeyerek eğer vagon Türkiye'de üretiliyorsa Türkiye'den alınmasının sağlanmasıdır [22]. Diğer alt sektörlerde de buna benzer önlem ve kararlarla rekabetçiliğimiz artırılabilir.

Akıllı Bölgesel Yenilik Stratejilerinde belirlenen öncelikli sektörler arasında raylı sistem sektörü bulunan bölgelerde ana ve yan sanayinin bir arada bulunduğu raylı sistem ihtisas sanayi bölgelerinin kurulması, kümelenmelerin desteklenmesi ve bu bölgelere özel teşviklerin sağlanması sektörün rekabet gücünün artmasına katkı sağlayacaktır. Sivas'ta kurulan Demirăg Organize Sanayi Bölgesi iltisak hatları ve sağlanan teşviklerle örnek teşkil etmektedir. Eskişehir'de raylı sistemler öncelikli sektör olarak belirlenmiş olup [23] benzer bir yapı burada da faaliyete geçirilmelidir.

Kamu alımları milli sanayimizin kalkınması için çok önemlidir. Son 4 yılın ortalama kamu alımı yıllık 188 milyar TL'dir. Kamu alımlarında her yıl \% 100 yerli ürün ve hizmet alımı yapılsa her y1l 188 milyar TL, 11. Kalkınma planı çerçevesinde \% 80 yerli ürün ve hizmet alımı yapılsa her yıl 152 milyar TL ülkemizde kalacak, işsizlik ve cari açı önlenecek, sanayimiz gelişecek ve ihracatımız artacaktır. 4734 Sayılı Kamu İhale Kanunu'nun yerli isteklilerle ilgili $\% 15$ avantaj düzenlemesi idareler tarafından farklı şekillerde kullanılmamalı ve mutlaka zorunlu hale getirilmelidir. Bazı Belediyeler Yurt dışı kredi sağladığında alımlarda yerli katkı şartı uygulamıyor. Kurulacak Yerlileştirme Başkanlığı bir otorite olarak bu alımlarda da en az \% 60 yerli katkı şartı getirmeli ve denetlemelidir. TL ile ihaleye çıkıldığında eskalasyon (kur farkı, enflasyon, vb) hesabı yapılmadığından yerli üreticilerimiz sorun yaşıyor. Proje süresinde oluşan ve öngörülmeyen bu farkların yerli üreticilerimizin zarar etmemesi için sözleşmeye yansıtılması gerekiyor. En önemli konulardan olan yurt dışında iş yapan müteahhitlerimiz her yıl yaklaşık 1 milyar Dolarlık iş almaktadır. Yerli ürünlerimizin müteahhitlerimiz tarafından tercih edilmesiyle hem yerli üretim, hem de ihracatımız artacaktır. Bu konuda kurulacak olan Yerlileştirme Başkanlığı teşvik ederek müteahhitlerimizle koordinasyon sağlayabilir. Bu gibi önlemlerle Türk demiryolu araçları, tramvaylar ve komponentleri sektörünün uluslararası arenada daha rekabetçi olması sağlanabilir.

Araştırmacılara yönelik olarak, ilgili sektöre yönelik yapılmış olan bu çalışmanın, farklı endekslere göre zayıf olunan alanlarla ilgili sektörel yapının çeşitli parametrelere göre geliştirilmesine yönelik bir çalışmanın yapılabileceği önerilebilir. Yine özel donatımlı konteyner üretiminin yeterli olmaması noktasına taşıma modları ve konteyner limanlarının mevcut durumu ve sayısı arasında etkileşim farklı bir çalışmada ele alınabilir. 


\section{Kaynakça}

[1] R. Li, C. Zheng, H. Wang, D. Zhao, B. Ran, and X. Xue, "Intersection traffic signal optimisation considering the impact of upstream curbside bus stops," IET Intelligent Transport Systems, vol. 14, no. 8, pp. 880-888, 2020, doi: 10.1049/iet-its.2019.0660

[2] Y. Dalgıç, Y.B. Ulutaş, S. Karasungur, "TR41 bölgesi rayll sistemler sektörü raporu; Dünü, Bugünü ve Geleceği," BEBKA, 2016

[3] M. Kılıç, T. Yalılı Kılıç, T. Dönmez, S. Adalı. "Karayolu ulaşımında yakıt tüketimine bağlı karbon ayak izi değişimi: Çanakkale örneği," Gümüşhane Üniversitesi Fen Bilimleri Enstitüsü Dergisi vol.11, no 3 pp. 943-955, 2021, doi: 10.17714/gumusfenbil.848016

[4] S. Şahin, "Malatya'da kent içi ulaşım ve toplu taşıma sistemlerinin karşılaştırmalı incelenmesi: Trambüs ve hafif raylı sistem örneği," Yüksek Lisans tezi, İnönü Üniversitesi Sosyal Bilimleri Enstitüsü, Malatya, 2020

[5] TÜDEMSAS, "Sivas demiryolu makine ve ekipmanlarl sektörü kümelenme stratejisi ve eylem planı raporu," 2013.

[6] İ. Pektaş, “Raylı ulaşım sistemleri sektör analizi,” ARUS Kümelenmesi, 2018

[7] T.C. Kalkınma Bakanlığ1, "Raylı sistem araçlarında yerli üretim çalışma grubu raporu,” 2018

[8] B. Balassa, "Trade liberalization and 'revealed' comparative advantage," Manchester School vol. 33, no. 2, pp. $99-123,1965$

[9] T. L. Vollrath, "A theoretical evaluation of alternative trade intensity measures of revealed comparative advantage," Weltwirtschafliches Archiv, vol.127, pp. 165-279, 1991

[10]B.C. Başer, O.A. Mutlu, A. Yılmaz. “Anadolu raylı ulaşım sistemleri kümelenmesi ihracatının artırılması projesi ihtiyaç analizi raporu,” ARUS Kümelenmesi, 2018

[11]İ. Pektaş, "Raylı sistemlerde en az \% 51 yerli katkı şartı tüm sektörlere örnek olacak." Demiryolu Mühendisliği, vol. 7, pp. 48-49, 2018

[12] A. Uğur. "Investigation of the world railway sector development prospects and turkey's status," Alphanumeric Journal, vol. 7, no. 2, pp. 369-398, 2019, doi: 10.17093/ alphanumeric.582290

[13]İ. Şenlik, "Kent içi raylı ulaşım sistemleri," Elektrik Mühendisliği Dergisi, no. 408, pp. 37-39 Eylül, 2016

[14]D. Ricardo, Principles of political economy and taxation, G. Bell and Sons, 1891

[15]E. Heckscher, "Utrikeshandelns verkan på inkomstfördelningen. några teoretiska grundlinjer," Ekonomisk tidskrift, vol 21, pp.1-32, 1919

[16]B. Ohlin, Interregional and international trade, Harvard University Press, 1933

[17]H. H. Liesner, "The European common market and British industry", Economic Journal, vol. 68 no.270, pp. 302-316, 1958

[18]B. Erkan, “Ülkelerin ihracat performanslarının belirlenmesinde açıklanmış karşılaştırmalı üstünlüklerinin kullanılması: yükselen ekonomiler örneği," Yayınlanmamış Doktora Tezi, Celal Bayar Üniversitesi SBE, Manisa, 2009

[19]K. Gürpınar, M. Barca, "Türk mobilya sektörünün uluslararası rekabet gücü düzeyi ve nedenleri," Eskişehir Osmangazi Üniversitesi İ̈BF Dergisi, vol.2, no.2, pp. 41- 43, 2007

[20] M. Ozan BAŞKOL, "Türk Otomotiv Sektörünün Uluslararası Rekabet Gücü”, PARADOKS Ekonomi, Sosyoloji ve Politika Dergisi, vol: 7, no. 2, pp. 63-78, 2011

[21]H. Çeştepe A.Tunçel, "Türkiye Demir Çelik Sektörünün Uluslararası Rekabet Gücü Analizi”, International Congress on Social Sciences II (INCSOS 2018 Quds) Volume 13/15, Spring 2018, p. 113-129

[22]Demiryolu Araçları Tescil ve Sicil Yönetmeliği, Ulaştırma, Denizcilik ve Haberleşme Bakanlığı, 16.07.2015.

[23]BEBKA, Bursa Eskişehir Bilecik Bölge Planı 2014-2023, 2015 


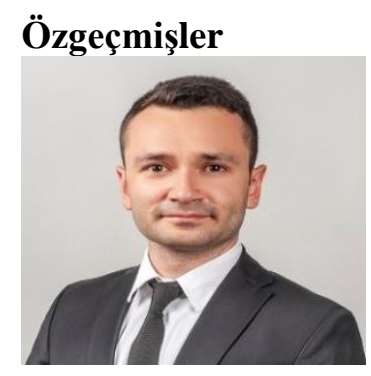

\section{Arif AKTAŞ}

Lisans eğitimini Karabük Üniversitesi Raylı Sistemler Mühendisliği Bölümünde tamamlamıştır. Halen Eskişehir Teknik Üniversitesi Raylı Sistemler Mühendisliği Anabilim Dalında yüksek lisans eğitimine devam etmektedir. 2019 yılından bu yana Anadolu Raylı Ulaşım Sistemleri Kümelenmesi'nde (ARUS) proje yöneticisi olarak çalışmaktadır.

e-posta: arif.aktas@ostim.org.tr

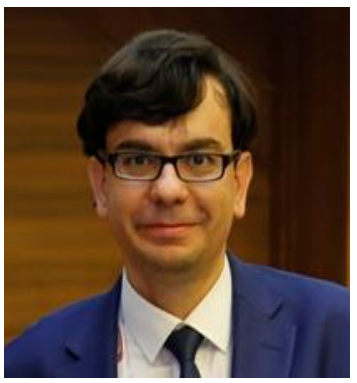

\section{Ömür AKBAYIR}

Lise eğitimini Demiryolu Meslek Lisesinde, lisans ve yüksek lisans eğitimini Eskişehir Osmangazi Üniversitesi'nde, doktora eğitimini Gazi Üniversitesi'nde tamamlamıştır. Onbeş yıl TCDD'nin çeşitli işyerlerinde, çeşitli görevler üstlenmiş olup, 2015 yllından bu yana Eskişehir Teknik Üniversitesi’nde Dr. Öğr. Üyesi olarak çalışmaktadır. e-posta: omurakbayir@eskisehir.edu.tr

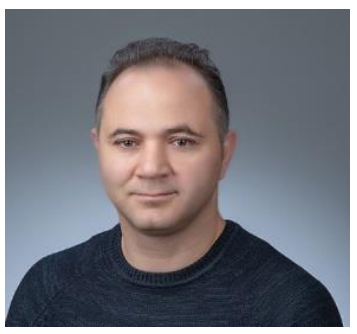

\section{Kadir AKSAY}

Lisans Eğitimini Gazi Üniversitesi İşletme Bölümü’nde, yüksek lisans eğitimini Anadolu Üniversitesi İşletme Anabilim Dalı Yönetim ve Organizasyon Bilim Dalı'nda ve doktora eğitimini Selçuk Üniversitesi İşletme Anabilim Dalı'nda tamamlamıştır. Halen Eskişehir Teknik Üniversitesi Ulaştırma Bilimleri Enstitüsü ve Ulaştırma Meslek Yüksek Okulu'nda Doç. Dr. olarak çalışmalarına devam etmektedir.

Beyanlar:

e-posta: kadiraksay@eskisehir.edu.tr

Bu makalede bilimsel araştırma ve yayın etiğine uyulmuştur.

Yazarların katkıları: Arif AKTAŞ: Kaynaklar, Görselleştirme, Yazma-gözden geçirme ve düzenleme. Ömür AKBAYIR: Kavramsallaştırma, Metodoloji. Kadir AKSAY: Doğrulama, İnceleme. 